\title{
François Dorval Langlois Sieur de Fancan, Le Tombeau des romans
}

\section{Chiara Rolla}

\section{(2) OpenEdition}

1 Journals

\section{Edizione digitale}

URL: https://journals.openedition.org/studifrancesi/39202

DOI: $10.4000 /$ studifrancesi.39202

ISSN: 2421-5856

\section{Editore}

Rosenberg \& Sellier

\section{Edizione cartacea}

Data di pubblicazione: 1 décembre 2004

Paginazione: 357

ISSN: 0039-2944

\section{Notizia bibliografica digitale}

Chiara Rolla, «François Dorval Langlois Sieur de Fancan, Le Tombeau des romans», Studi Francesi

[Online], 143 (XLVIII | II) | 2004, online dal 30 novembre 2015, consultato il 19 mai 2021. URL: http:// journals.openedition.org/studifrancesi/39202 ; DOI: https://doi.org/10.4000/studifrancesi.39202

Questo documento è stato generato automaticamente il 19 mai 2021.

\section{(c) $(1) \&$}

Studi Francesi è distribuita con Licenza Creative Commons Attribuzione - Non commerciale - Non opere derivate 4.0 Internazionale. 


\title{
François Dorval Langlois Sieur de Fancan, Le Tombeau des romans
}

\author{
Chiara Rolla
}

\section{NOTIZIA}

FRANÇOIS DORVAL LANGLOIS SIEUR DE FANCAN, Le Tombeau des romans, Préface et notes de Franck GREINER, Presses Universitaires de Reims, 2003, p. 114.

1 L'opera di Fancan costituisce, con i testi di Sorel, Chapelain, Huet e Du Plaisir, uno dei rari documenti critici su un genere ancora in formazione durante i regni di Luigi XIII e XIV che il Seicento ci ha consegnato. Se inserito infatti nel più vasto panorama delineato dai paratesti che accompagnano i romanzi della prima metà del XVII secolo, esso rappresenta una testimonianza importante del dibattito in corso attorno alla formazione della poetica narrativa.

2 L'edizione critica di Greiner, che riproduce il testo del 1626, restituisce allo studioso moderno un tassello importante per delineare più chiaramente e in modo più completo un panorama a cui già le antologie di Coulet e di Berger avevano contribuito in maniera decisiva.

3 Il testo, riprodotto rispettando scrupolosamente l'ortografia e le note a margine dell'edizione originale, è preceduto da un' introduzione, nella quale Greiner affronta i problemi inerenti la paternità dell'opera, le fonti, le caratteristiche linguistiche e stilistiche e le teorie espresse. Da quest'ultimo punto di vista manca però un riferimento più preciso e puntuale al dibattito narrativo emergente dall'analisi dei paratesti dei romanzi del periodo, importanti testi teorici di riferimento per l'epoca. L'indice dei nomi citati che chiude il volume è senza dubbio un utile strumento di consultazione e di analisi. 